\title{
A radioimmunological assay for naturally occurring insect juvenile hormones using iodinated tracers : Its use in the analysis of biological samples
}

\author{
par J. C. BAEHR, P. PRADELLES*, F. DRAY* \\ Université Pierre et Marie Curie, Laboratoire de Cytophysiologie des Arthropodes, \\ ERA 620, CNRS, 105, Boulevard Rospail, 75006 Paris. \\ * FRA no 8 INSERM, Unité de Radioimmunologie Analytique, Institut Pasteur, \\ 28, Rue du Dr. Roux, 75724 Paris Cedex 15.
}

Summary. Three sensitive and specific radioimmunological assays (RIA) using iodinated tracers have been developed for the quantitative measurement of naturally occurring juvenile hormone $(\mathrm{JH})$. The antigens were prepared by binding the JH's to human serum albumin. lodinated tracers were prepared by binding histamine to the $\mathrm{JH}$ molecule, and then subsequently binding one molecule of ${ }^{125}$ per molecule of histamine. The RIA's were carried out in $0.02 \mathrm{M}$ phosphate buffer containing $0.1 \mathrm{p} .100$ of BSA. The assay detection limit was $20 \mathrm{pg}$ for all the three juvenile hormones. RIA sensitivity (at $B / B O=50$ p. 100) of $\mathrm{JH}_{1}, \mathrm{JH}_{2}$ and $\mathrm{JH}_{3}$ was $0.75,1$ and $2.6 \mathrm{ng} / \mathrm{ml}$, respectively. Antiserum to $\mathrm{JH}_{1}$ cross-reacted 7.3 p. 100 with $\mathrm{JH}_{2}$ and 0.8 p. 100 with $\mathrm{JH}_{3}$; antiserum to $\mathrm{JH}_{2}$ cross-reacted 26 p. 100 with $\mathrm{JH}_{1}$ and 12 p. 100 with $\mathrm{JH}_{3}$, and antiserum to $\mathrm{JH}_{3}$ cross-reacted 0.3 p. 100 with $\mathrm{JH}_{1}$ and 0.9 p. 100 with $\mathrm{JH}_{2}$. Various methods of preparing biological samples for the RIA of JH's have been described.

Radioimmunological assays (RIA) are useful tools in investigative research, and are commonly used in the field of vertebrate physiology. In insect physiology, radioimmunoassays for ecdysteroids are used routinely in many laboratories. However, the first RIA described for JH's (fig. 1) (Laver ef al., 1974), which used a tritiated tracer, was not sufficiently sensitive to measure the low levels of hormone present. We have developed a RIA for $\mathrm{JH}_{1}$ (Baehr ef al., 1976), and more recently for $\mathrm{JH}_{2}$ and $\mathrm{JH}_{3}$, using high specific activity ${ }^{125}$-labelled tracers. The present work describes the preparation of the immunogens and the iodinated tracers, the methods used for the assays,

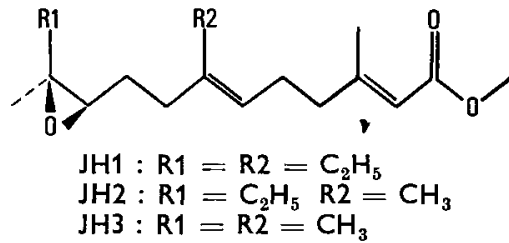

FIG. 1. - Structures of three natural juvenile hormones. 
and their sensitivity and specificity. The application of these assays to the measurement of juvenile hormones in biological material is discussed.

\section{Methods and results.}

\section{JH Radioimmunoassay.}

When the RIA for $\mathrm{JH}_{1}$ was being developed, each step in the preparation of the immunogen and the iodinated tracer could be controlled by using a tritiated $\mathrm{JH}_{1}$ tracer $\left(\mathrm{JH}_{1}, \mathrm{NEN}, 13 \mathrm{Ci} / \mathrm{mM}\right.$ ) (Baehr et al., 1976). Radioactively-labelled $\mathrm{JH}_{2}$ and $\mathrm{JH}_{3}$ were not available ; immunogens and iodinated tracers for the assay of these two hormones were prepared by following the methodology devised for $\mathrm{JH}_{1}$. The $\mathrm{JH}_{1}$ was the generous gift of Roussel Uclaf (Romainville, France) ; the $\mathrm{JH}_{2}$ and $\mathrm{JH}_{3}$ were obtained from Calbiochem (San Diego, California, USA).

Preparation of the immunogen. $-20 \mathrm{mg}$ of juvenile hormones were dissolved in $0.25 \mathrm{ml}$ of methanol and mixed with $15 \mu \mathrm{Ci}$ of tritiated hormone (for the preparation of the $\mathrm{JH}_{1}$ immunogen only); $0.4 \mathrm{ml}$ of methanol $/ \mathrm{NaOH}(2 \mathrm{~N})(\mathrm{v} / \mathrm{v})$ was added to the

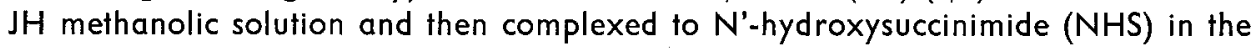
presence of $\mathrm{N}-\mathrm{N}^{\prime}$-dicyclohexyl-carbodiimide. In an alkaline medium, an amino radical of the lysine of human serum albumin was substituted for NHS. On the basis of isotopic dilution twenty six molecules of acid $\mathrm{JH}$ were fixed per molecule of HSA.

Immunization schedule. - For each immunogen, five white rabbits were immunized intradermally with $600 \mu \mathrm{g}$ of the conjugate emulsified in complete Freund's adjuvant. Booster injections were given intradermally with same amount of conjugate at 5-week intervals. The animals were first bled 10 days after booster injection and then weekly. The best blood samples were obtained 2 or 3 weeks after the second booster injection. For each immunogen, two rabbits gave antisera with a high binding level.

Preparation of the iodinated tracer. - In an alkaline medium, one molecule of histamine was substituted for the NHS in the JH-NHS complex. The JH-histamine (JH-His) was labelled with ${ }^{125}$ using the chloramine $\mathrm{T}$ method. To $1.5 \mathrm{nmol}$ of $\mathrm{JH}-\mathrm{His}$ in $5 \mu \mathrm{l}$ of PBS $0.5 \mathrm{M}, \mathrm{pH} 7.4$, were added $320 \mu \mathrm{Ci}$ of ${ }^{125}$ and $4 \mu \mathrm{l}$ of chloramine $\mathrm{T}$ (3 $\mathrm{mg} / \mathrm{ml}$ in $0.05 \mathrm{M}$ PBS, $\mathrm{pH} 7.4$ ). After $1 \mathrm{~min}$, the reaction was stopped by $4 \mu \mathrm{l}$ of sodium metabisulfite (15 $\mathrm{mg} / \mathrm{ml}$ in $0.05 \mathrm{M}$ PBS, $\mathrm{pH} 7.4$ ).

The reaction products were purified by TLC (chloroform/methanol/water $80: 20: 2$ on silica gel plate F254 Merck); a labelled compound $\left(R_{F}=0.64\right)$ was separated from unlabelled JH-His $\left(R_{F}=0.40\right)$ and free iodine $\left(R_{F}=0.03\right)$. The yield of iodination was estimated to be 30 p. 100 (on the basis of the isotopic dilution of unlabelled $\mathrm{JH}-\mathrm{His}$ ). Since the excess of JH-His in proportion to the amount of iodine did not allow diiodo-derivative synthesis, the specific activity of the $\mathrm{JH}-\mathrm{His}-{ }^{125}$ | was close to the theoretical value of $2000 \mathrm{Ci} / \mathrm{mmol}$.

Radioimmunoassay. - JH is strongly adsorbed onto a variety of substrates (Giese, Spindler and Emmerich, 1977). This adsorption was reduced in our experiments by carrying out the assay in an aqueous medium using a $0.02 \mathrm{M}$ phosphate buffer containing 0.1 p. 100 of BSA (fraction V). In these conditions, there was about 0.2 p. 100 adsorp- 
tion onto siliconized glassware (1 p. 100 siliclad), about 1.5 p. 100 onto polystyrene, and about 1.4 p. 100 onto Eppendorf cones. In the absence of BSA, adsorption onto plastic materials was about 40 p. 100.

$100 \mu \mathrm{l}$ of the sample to be assayed, $100 \mu \mathrm{l}$ of the tracer and $100 \mu \mathrm{l}$ of diluted antiserum were pipetted successively into polystyrene tubes. The reaction was allowed to equilibrate at $20^{\circ} \mathrm{C}$ for $2 \mathrm{hrs}$ or at $4{ }^{\circ} \mathrm{C}$ for $12 \mathrm{hrs}$; it was then stopped by the addition of $1 \mathrm{ml}$ dextran-coaded charcoal (Norit A, $2.5 \mathrm{~g}$, Dextran T70, $0.25 \mathrm{mg}$ in $100 \mathrm{ml}$ buffer) to each tube. After incubation at $0{ }^{\circ} \mathrm{C}$ for $20 \mathrm{~min}$, the tubes were centrifuged at $2200 \mathrm{~g}$ for $20 \mathrm{~min}$ at $4{ }^{\circ} \mathrm{C}$. The radioactivity in the precipitate was counted in a gamma counter.

The antisera having the best sensitivity also showed the best specificity and elevated antibody concentration. Only these antisera were used routinely. They were diluted $1 / 300000$ to give a binding of 30 to 40 p. 100 in the absence of any added $\mathrm{JH}(\mathrm{Bo})$. The sensitivity of the $\mathrm{JH}_{1}, \mathrm{JH}_{2}$ and $\mathrm{JH}_{3}$ assays $(\mathrm{B} / \mathrm{Bo}=50 \mathrm{p} .100)$ were 0.75 , 1 and $2.6 \mathrm{ng} / \mathrm{ml}$, respectively (fig. 2).

The standard deviations for the three assays were $0.10 \mathrm{ng} / \mathrm{ml}(10 \mathrm{pg} /$ tube $)$.

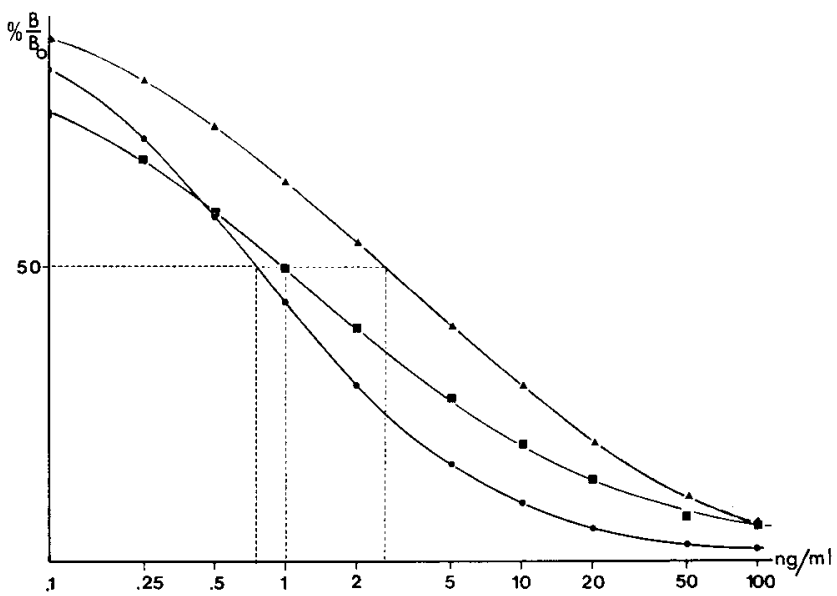

FIG. 2. - Inhibition of labelled $\mathrm{JH}_{1}$ binding to anti $J H_{1}$ in the presence of increasing amounts of unlabelled $\mathrm{JH}_{1}(\boldsymbol{\bullet})$.

Inhibition of labelled $\mathrm{JH}_{2}$ binding to anti $\mathrm{JH}_{2}$ in the presence of increasing amounts of unlabelled $\mathrm{JH}_{2}(\mathbf{a})$. Inhibition of labelled $\mathrm{JH}_{3}$ binding to anti $\mathrm{JH}_{3}$ in the presence of increasing amounts of unlabelled $\mathrm{JH}_{3}(\mathbf{\Lambda})$.

The cross reactions for the three JH's were as follows:

\begin{tabular}{lccc}
\hline & $\mathrm{JH}_{1}(\mathrm{p} .100)$ & $\mathrm{JH}_{2}(\mathrm{p} .100)$ & $\mathrm{JH}_{3}(\mathrm{p} .100)$ \\
\hline Anti $\mathrm{JH}_{1} \ldots \ldots \ldots \ldots \ldots$ & 100 & 7.3 & 0.8 \\
\hline Anti $\mathrm{JH}_{2} \ldots \ldots \ldots \ldots \ldots$ & 26 & 100 & 12 \\
\hline Anti $\mathrm{HJ}_{3} \ldots \ldots \ldots \ldots \ldots$ & 0.3 & 0.9 & 100 \\
\hline
\end{tabular}


The specificity of the antisera raised against $\mathrm{JH}_{1}$ and $\mathrm{JH}_{3}$ was satisfactory, but that of the antiserum to $\mathrm{JH}_{2}$ could be improved. An increased sensitivity of all three assays would mean that the volume of biological sample required could be reduced.

Attemps to improve RIA sensitivity and specificity. - A study of the cross reactions of the antiserum directed against $\mathrm{JH}_{1}$ showed that the $\mathrm{JH}_{1}$-histamine complex had a cross-reaction of 210 p. 100 as compared with the $\mathrm{JH}_{1}$ (Baehr ef al., 1976). The greater affinity for the iodinated tracer than for the $\mathrm{JH}_{1}$ resulted in an RIA of lower sensitivity than that which could be achieved using a tracer of lower affinity but with the same specific radioactivity. The presence of a carboxy amino link in $C_{1}$ in the immunogen explained the strong affinity of the antibodies for this structure, which was also found in the $\mathrm{JH}-\mathrm{His}$ complex.

The use of heterologous tracers improved the sensitivity and specificity of the RIA to some extent (see table 1).

TABLE 1

Variations of RIA sensitivity with combinations of the different incubation sysfems.

$A=$ anti $J_{1}, A^{\prime}==J H_{1}, A^{\prime \prime}:=J_{1}-H_{1}$ is-125l,

$$
B=\text { anti } \mathrm{JH}_{2}, \mathrm{~B}^{\prime}=\mathrm{JH}_{2}, \mathrm{~B}^{\prime \prime}=\mathrm{JH}_{2}-\mathrm{H}^{\prime} \mathrm{C}^{\prime 125}, \mathrm{C}=\text { anti } \mathrm{JH}_{3}, \mathrm{C}^{\prime}=\mathrm{JH}_{3} \text {, }
$$

\begin{tabular}{|c|c|c|c|c|c|}
\hline Antisera & $\begin{array}{l}\text { Cold } \\
\text { standard }\end{array}$ & $\begin{array}{l}\text { lodinated } \\
\text { tracer }\end{array}$ & $\begin{array}{c}50 \text { p. } 100 \text { sensitivity } B / B_{0} \\
(\mathrm{ng} / \mathrm{ml})\end{array}$ & $B_{0}$ p. $100\left(\frac{B-T}{A T}\right)$ & $\begin{array}{c}\text { Antiserum initial } \\
\text { dilution }\end{array}$ \\
\hline 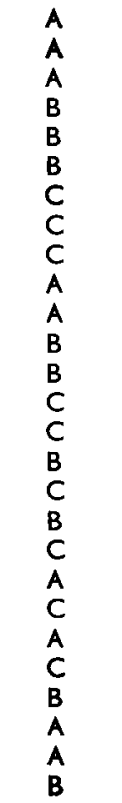 & $\begin{array}{l}\mathbf{A}^{\prime} \\
\mathbf{B}^{\prime} \\
\mathbf{C}^{\prime} \\
\mathbf{B}^{\prime} \\
\mathbf{A}^{\prime} \\
\mathbf{C}^{\prime} \\
\mathbf{C}^{\prime} \\
\mathbf{A}^{\prime} \\
\mathbf{B}^{\prime} \\
\mathbf{A}^{\prime} \\
\mathbf{A}^{\prime} \\
\mathbf{B}^{\prime} \\
\mathbf{B}^{\prime} \\
\mathbf{C}^{\prime} \\
\mathbf{C}^{\prime} \\
\mathbf{A}^{\prime} \\
\mathbf{A}^{\prime} \\
\mathbf{C}^{\prime} \\
\mathbf{B}^{\prime} \\
\mathbf{B}^{\prime} \\
\mathbf{B}^{\prime} \\
\mathbf{C}^{\prime} \\
\mathbf{A}^{\prime} \\
\mathbf{A}^{\prime} \\
\mathbf{B}^{\prime} \\
\mathbf{C}^{\prime} \\
\mathbf{C}^{\prime}\end{array}$ & $\begin{array}{l}\mathrm{A}^{\prime \prime} \\
\mathrm{A}^{\prime \prime} \\
\mathrm{A}^{\prime \prime} \\
\mathrm{B}^{\prime \prime} \\
\mathrm{B}^{\prime \prime} \\
\mathrm{B}^{\prime \prime} \\
\mathrm{C}^{\prime \prime} \\
\mathrm{C}^{\prime \prime} \\
\mathrm{C}^{\prime \prime} \\
\mathrm{B}^{\prime \prime} \\
\mathrm{C}^{\prime \prime} \\
\mathrm{A}^{\prime \prime} \\
\mathrm{C}^{\prime \prime} \\
\mathrm{A}^{\prime \prime} \\
\mathrm{B}^{\prime \prime} \\
\mathrm{A}^{\prime \prime} \\
\mathrm{A}^{\prime \prime} \\
\mathrm{A}^{\prime \prime} \\
\mathrm{A}^{\prime \prime} \\
\mathrm{B}^{\prime \prime} \\
\mathrm{B}^{\prime \prime} \\
\mathrm{B}^{\prime \prime} \\
\mathrm{B}^{\prime \prime} \\
\mathrm{C}^{\prime \prime} \\
\mathrm{C}^{\prime \prime} \\
\mathrm{C}^{\prime \prime} \\
\mathrm{C}^{\prime \prime}\end{array}$ & $\begin{array}{r}0.75 \\
10.17 \\
93.80 \\
1.00 \\
3.80 \\
7.93 \\
2.60 \\
866.00 \\
288.10 \\
0.47 \\
0.79 \\
3.60 \\
1.00 \\
2.42 \\
2.60 \\
9.13 \\
50.95 \\
31.58 \\
27.75 \\
1.58 \\
30.34 \\
15.56 \\
44.55 \\
50.21 \\
6.03 \\
16.61 \\
7.14\end{array}$ & $\begin{array}{l}33 \\
33 \\
33 \\
31 \\
31 \\
31 \\
33 \\
33 \\
33 \\
33 \\
34 \\
40 \\
30 \\
35 \\
38 \\
37 \\
45 \\
35 \\
40 \\
31 \\
42 \\
34 \\
46 \\
40 \\
34 \\
36 \\
42\end{array}$ & $\begin{array}{r}100000 \\
100000 \\
100000 \\
100000 \\
100000 \\
100000 \\
100000 \\
100000 \\
100000 \\
50000 \\
10000 \\
100000 \\
30000 \\
25000 \\
35000 \\
50000 \\
25000 \\
50000 \\
25000 \\
50000 \\
35000 \\
50000 \\
35000 \\
30000 \\
10000 \\
10000 \\
30000\end{array}$ \\
\hline
\end{tabular}

$\mathrm{JH}_{1}$ assay : homologous assay sensitivity $(\mathrm{B} / \mathrm{Bo}=50 \mathrm{p} .100)$ was about $0.75 \mathrm{ng} / \mathrm{ml}$, which fell to $0.47 \mathrm{ng} / \mathrm{ml}$ using $\mathrm{JH}_{2}-\mathrm{His}^{-125}$ (anti $\mathrm{JH}_{1}+\mathrm{JH}_{1}+\mathrm{JH}_{2} \mathrm{His}{ }^{125}$ ). In these 
conditions, cross-reactions with $\mathrm{JH}_{2}$ and $\mathrm{JH}_{3}$ were 29 and 3 p. 100 , respectively, as compared with 7.3 and 0.8 p. 100 . The use of the $\mathrm{JH}_{3}-\mathrm{His}-{ }^{125}$ tracer did not improve sensitivity or specificity.

$\mathrm{JH}_{2}$ assay : homologous assay sensitivity $(\mathrm{B} / \mathrm{Bo}=50$ p. 100) was about $1 \mathrm{ng} / \mathrm{ml}$, which was not improved when other combinations were used. The system (anti $\mathrm{JH}_{2}+\mathrm{JH}_{2}+\mathrm{JH}_{3}-\mathrm{His}^{125}$ ) did not alter sensitivity $(1 \mathrm{ng} / \mathrm{ml})$, but improved specificity for $\mathrm{JH}_{1}$. The cross-reactions with $\mathrm{JH}_{1}$ and $\mathrm{JH}_{3}$ were 1.9 and 14 p. 100 , respectively, as compared with 26 and 12 p. 100.

$\mathrm{JH}_{3}$ assay : no alteration significantly impoved either sensitivity or specificity.

The modification of the $\mathrm{JH}_{1}$ assay (using the $\mathrm{JH}_{2}-\mathrm{His}-125 \mid$ tracer) may be used in the routine method, since it definitely increased sensitivity. Although there was a loss of specificity in regard to the other JH's, the system could be applied to assay $\mathrm{JH}_{1}$ after separation from $\mathrm{JH}_{2}$ and $\mathrm{JH}_{3}$ by high-performance liquid chromatography (HPLC) (see below).

The use of the $\left.\mathrm{JH}_{3}-\mathrm{His}-{ }^{125}\right]$ tracer for the assay provided satisfactory sensitivity, increased the cross-reaction with $\mathrm{JH}_{1}$, and caused a negligeable loss in the crossreaction with $\mathrm{JH}_{3}$.

None of the other combinations showed any advantages; unfortunately, a sensitive system was not found in which the three JH's were similarly recognized.

\section{Application of juvenile hormone RIA to biological samples.}

RIA is a rapid technique which lends itself to the routine analysis of large numbers of biological samples. Extraction and purification techniques should be effective without being too laborious. Many techniques have been tested; only those giving the most satisfactory results are reported here.

Sampling and extraction of $\mathrm{JH}$ 's.

- Haemolymph : a known volume of haemolymph was taken up in a calibrated capillary tube, and 100 to $200 \mu \mathrm{l}$ were placed in at least twice their volume of methanol/diethyl ether $(1: 1, v / v)$. To prevent the action of esterases this operation must be carried out as rapidly as possible. A known amount of tritiated $\mathrm{JH}_{1}(9,000 \mathrm{dpm}$, $13 \mathrm{Ci} / \mathrm{mM}$ ) was added to each sample to measure the recovery of $\mathrm{JH}$ which was extracted, purified and redissolved in a buffer prior to assay. The samples were stored in the methanol/diethyl ether mixture at $-30^{\circ} \mathrm{C}$.

The juvenile hormones were extracted by hexane ( 8 volumes of hexane per volume of methanol/diethyl ether/sample) ; this mixture was homogenized supersonically for $1 \mathrm{~min}$ and then centrifuged at $3500 \mathrm{~g}$ for $20 \mathrm{~min}$ at $4^{\circ} \mathrm{C}$. The upper phase containing the JH's was removed; recovery was between 96 and 100 p. 100. The lower phase contained the ecdysones, which could also be assayed by RIA.

- Whole insects or insect organs : the samples were homogenized in a mixture of diethyl ether/methanol $1: 1, v / v)$ (2 volumes of solvent for 1 volume of sample) and were then treated as described above for the heamolymph.

Extract purification.

Schooley (1977) has reviewed several techniques for the purification of JH's from biological extracts. The following methods were tested in these experiments : cold 
precipitation of lipids ; thin layer chromatography ; chromatography on celite column, aluminium oxide column, silica gel column, and Sephadex LH-20 gel column, and high performance liquid chromatography (HPLC). When possible, the same extract was assayed after purification by these different techniques. Preliminary results showed that the first three methods did not separate JH's from other substances which interfered with the assay (negative dilution test), and gave only low recoveries. These three were therefore discarded.

Chromatography on Sephadex LH-20 gel (gel permeation) : several solvent systems were used (benzene/acetone $1 / 1$; benzene/methanol $1 / 1$; methanol alone). Although the technique was laborious, it was the best method for purifying lipid-rich samples.

Chromatography on aluminium oxide column : the column consisted of Pasteur pipettes $5.7 \mathrm{~mm}$ in diameter packed with $3 \mathrm{~cm}$ of aluminium oxide powder (activity, 2-3 Merck) and then with $3 \mathrm{~cm}$ of disodium phosphate. The extracts, redissolved in $2 \mathrm{ml}$ of hexane, were placed on the column and eluted with $1 \mathrm{ml}$ of hexane/benzene, $1 / 1$, then with $3 \mathrm{ml}$ of benzene. The $\mathrm{JH}$ 's were eluted in the benzene fraction with a recovery of about 95 p. 100 . In these conditions, the $\mathrm{JH}$ acid and diol forms were eluted by more polar solvents than benzene. The column blanks were less than $10 \mathrm{pg} /$ column.

Chromatography on silica gel : the column consisted of Pasteur pipettes $5.7 \mathrm{~mm}$ in diameter with a $5 \mathrm{~cm}$ silica gel stationary phase (Merck, granulation less than $0.063 \mathrm{~mm}$ ). The sample, in $2 \mathrm{ml}$ of hexane, was placed on the column and eluted with $2 \mathrm{ml}$ of hexane/diethyl ether $95 / 5,2 \mathrm{ml}$ of hexane/diethyl ether $90 / 10$ and $5 \mathrm{ml}$ of benzene/diethyl ether 85/15. The JH's were eluted in the last phase. JH break down products (acids and diols) were eluted by the more polar solvents. Recovery was about 95 p. 100 and the column blanks were less than 10 pg/column.

High-performance liquid chromatography (HPLC) : it was necessary to purify the extracts before injecting them onto the column. Aluminium oxide or silica gel columns are well adapted to this purpose.

Normal phase columns $(30 \mathrm{~cm} \times 0.7 \mathrm{~mm} \mu$ Porasil Waters Associates $)$ and reverse phase columns ( $30 \mathrm{~cm} \times 0.7 \mathrm{~mm} \mathrm{C}_{18} \mu$ Bondapaks, Waters Associates) were tested. In normal phase, the JH's were eluted in 9-11 min (hexane/diethyl ether, 96/4, $1.5 \mathrm{ml} / \mathrm{min}$ ), and it was difficult to separate them in those conditions. In reverse phase (methanol/water, $4 / 6,1.5 \mathrm{ml} / \mathrm{min}$ ) the $\mathrm{JH}_{3}$ was eluted in $8 \mathrm{~min}$, the $\mathrm{JH}_{2}$ in $10 \mathrm{~min}$ and the $\mathrm{JH}_{1}$ in $13 \mathrm{~min}$. Recovery was 93 p. 100 in both systems, and the blancks were below $5 \mathrm{pg} / \mathrm{ml}$ of elution.

Results were obtained rapidly using the aluminium oxide column or silica gel column chromatography. Their effectiveness was validated by comparing the results of $\mathrm{JH}_{1}$ RIA (homologous assay) of an aliquot of the same extract either without purification or after purification on aluminium oxide column alone, purification on aluminium oxide column plus normal phase HPLC or purification on aluminium oxide column plus normat and reverse phase HiPLC. After correcting the results for recovery, similar values were obtained for 13 samples assayed after the three different types of purification. The amounts measured in crude extracts were much higher than those measured in purified extracts. 
Redissolution in the buffer for RIA.

Whatever purification technique was used, the JH's were collected in an organic phase and the solvents had to be evaporated before redissolving the extract in the buffer for RIA. The JH's dissolved poorly in the buffer and recovery was generally low ; it could be improved by using one of the following techniques :

- extract taken up in methanol (1/3 of the final volume), shaken and buffer is added ( $2 / 3$ of the final volume). The RIA was unaffected by this amount of methanol (which equalled $1 / 9$ of the final RIA incubation volume) ;

- extract taken up in buffer and supersonically treated for $1 \mathrm{~min}$, then shaken for $1 \mathrm{hr}$ at $37^{\circ} \mathrm{C}$.

After either of these procedures, total recovery (extraction, purification on aluminium oxide or silica gel column, redissolution in the buffer) was between 70 and 80 p. 100.

\section{Discussion.}

The endogenous levels of $\mathrm{JH}$ reported in the literature are very variable. This is probably due to the many different methods of extraction used. The concentrations reported are of the order of $\mathrm{ng} / \mathrm{g}$ or of $\mathrm{ng} / \mathrm{ml}$ of haemolymph, which are compatible with the synthetic capacity of the corpora allata in vitro (Pratt and Tobe, 1974). Radioimmunoassay (limit of detection, 10 to 20 pg) is useful in the assay of JH's in biological samples; the specificity of the antibodies is such that the different JH's may be quantitatively measured individually.

The three JH's may be assayed (each assay carried out in duplicate) using only $200 \mu \mathrm{l}$ of haemolymph, and the volume of haemolymph required may be further decreased by reducing the incubation volumes.

$U_{p}$ to 150 samples may be assayed by one person in one week. These assays have already been used to study the variations of $\mathrm{JH}$ levels during growth and reproduction in some insect species (table 2) and for direct measurement of the JH's in a culture medium (table 2).

As compared to biological assays, RIA has the advantage of being specific and rapid, and requiring only small amounts of biological material. As compared with physico-chemical techniques, such as electron capture or mass spectrometry, RIA is as sensitive (see Schooley, 1977), less expensive and more rapid, also requiring smaller amounts of biological material.

In addition to the dilution test (serial dilution assay of the same biological sample) and the addition test (recovery of a known quantity of JH from a biological sample), which were positive, the validity of RIA was demonstrated by comparing the JH levels in the haemolymph of normal insects and those treated with Procecene II. The larvae of Locusta migratoria treated with Precocene II (100 $\mu \mathrm{g} /$ animal in $100 \mu \mathrm{l}$ of acetone) during the first $24 \mathrm{hrs}$ of the fourth stage, moult into adult-like forms with an atrophied corpara allata (Pener, Orshan and de Wilde, 1978 ; Schooneveld, 1978, 1979). Radioimmunoassay of the $\mathrm{JH}$ levels in these Prococene treated fourth stage larvae revealed 


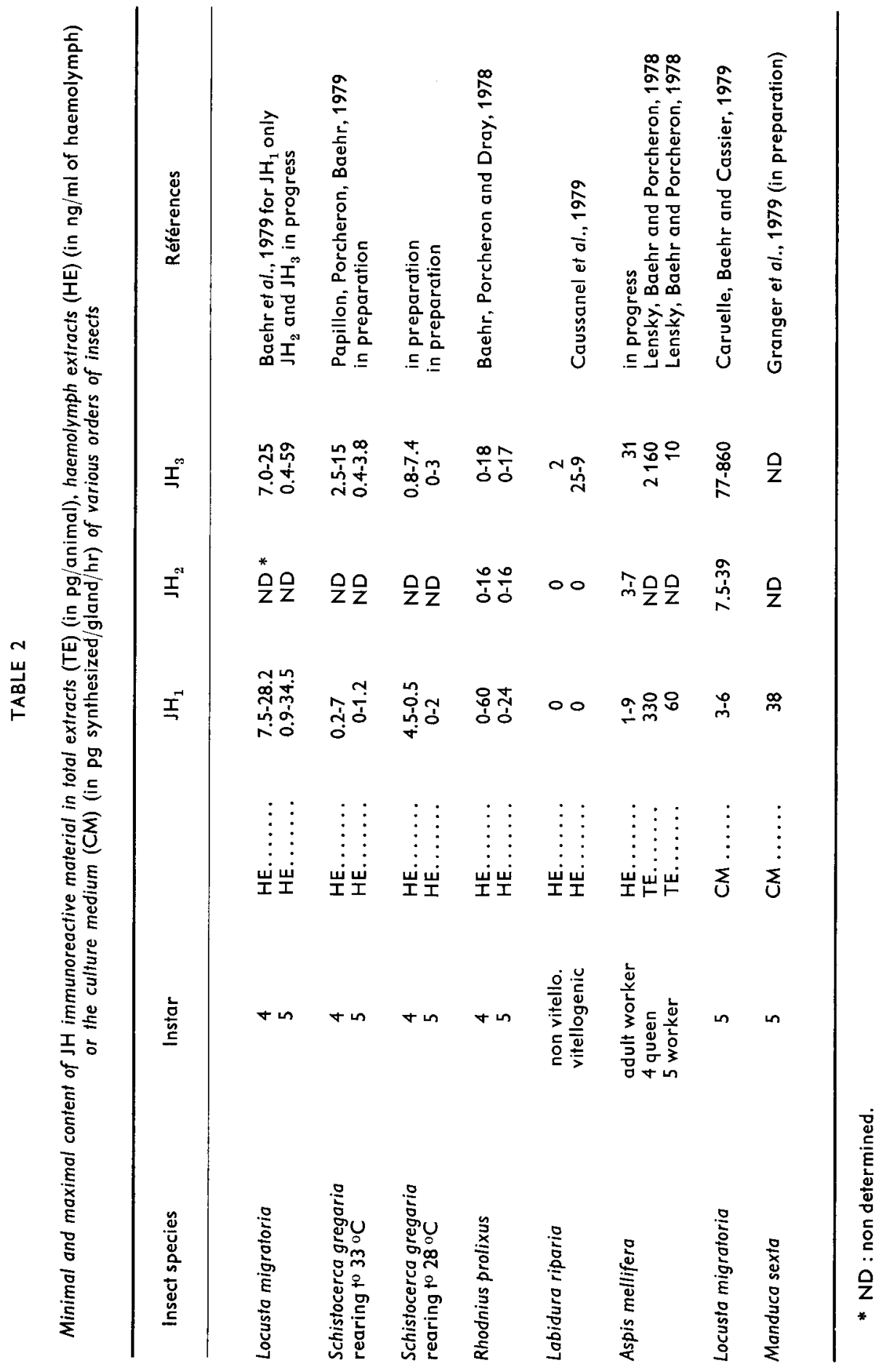


that in the 3 days following Precocene application, the $\mathrm{JH}$ levels dropped to almost zero (table 3).

\section{TABLE 3}

Juvenile hormone immunoreactive material in control and Precocene-treated Locusta migratoria fourth instar larvae. $\mathrm{JH}$ levels are expressed in $\mathrm{ng} / \mathrm{ml}$ of haemolymph. For each $\mathrm{JH}$ titre determination, the haemolymph of 5 to 7 insects was pooled. (In this experiment, the JH levels of control animals were lower than in normal animals (Baehr ef al., 1979) because the controls, as the treated animals, were kept in a dark room to prevent Precocene breakdown)

Time after Precocene application

\begin{tabular}{|c|c|c|c|c|c|c|c|c|c|c|c|c|}
\hline & \multicolumn{3}{|c|}{$6 \mathrm{~h}$} & \multicolumn{3}{|c|}{$24 \mathrm{~h}$} & \multicolumn{3}{|c|}{$48 \mathrm{~h}$} & \multicolumn{3}{|c|}{$72 \mathrm{~h}$} \\
\hline & $\mathrm{JH}_{1}$ & $\mathrm{JH}_{2}$ & $\mathrm{JH}_{3}$ & $\mathrm{JH}_{1}$ & $\mathrm{JH}_{2}$ & $\mathrm{JH}_{3}$ & $\mathrm{JH}_{1}$ & $\mathrm{JH}_{2}$ & $\mathrm{JH}_{3}$ & $\mathrm{JH}_{1}$ & $\mathrm{JH}_{2}$ & $\mathrm{JH}_{3}$ \\
\hline Control ........ & 2.44 & 0.88 & 1.83 & 1.72 & 1.56 & 1.72 & 1.42 & 1.69 & 1.69 & 1.59 & 2.16 & 4.16 \\
\hline Precocene-treated & 2.10 & 5.50 & 7.50 & 1.23 & 1.02 & 2.87 & 0.73 & 0.99 & 0.31 & 0.62 & 0.25 & 0.31 \\
\hline
\end{tabular}

The disappearance of the immunoreactive substance in chemically allatectomized insects argues in favor of RIA validity which, however, cannot be extended to other, cases. Since insect material is heterogeneous, the appropriate purification technique removing the substances binding aspecifically to the antibody or the tracer, must be selected in each case.

Reçu en mai 1979.

Accepté en juin 1979.

Résumé. Trois dosages radioimmunologiques (RIA) sensibles et spécifiques ont été mis au point pour le dosage de chacune des hormones juvéniles (JHs) naturelles d'insectes. Les immunogènes ont été préparés en couplant la JH à la sérum albumine humaine. Des traceurs iodés ont été obtenus en couplant une molécule d'histamine à la JH puis en fixant une molécule d'iode 125 par molécule d'histamine.

Les RIA sont effectués dans du tampon phosphate $0,02 \mathrm{M}$ contenant $0,1 \mathrm{p} .100$ de BSA ; la limite de détection des dosages est de $20 \mathrm{pg}$ pour chaque $\mathrm{JH}$. La sensibilité des RIA $\left(B / B o=50\right.$ p. 100) pour la $\mathrm{JH}_{1}$, la $\mathrm{JH}_{2}$ ef la $\mathrm{JH}_{3}$ sont respectivement de $0,75 \mathrm{ng} / \mathrm{ml}, 1 \mathrm{ng} / \mathrm{ml}$ et $2,6 \mathrm{ng} / \mathrm{ml}$. Les antisérums dirigés contre la J $\mathrm{H}_{1}$ croisent à $7,3 \mathrm{p}$. 100 avec la $\mathrm{JH}_{2}$ ef 0,8 p. 100 avec la $\mathrm{JH}_{3}$, les antisérums dirigés contre la $\mathrm{JH}_{2}$ croisent à 26 p. 100 avec la $\mathrm{JH}_{1}$ et 12 p. 100 avec la $\mathrm{JH}_{3}$ et les antisérums dirigés contre la $\mathrm{JH}_{3}$ croisent à 0,3 p. 100 avec la $\mathrm{JH}_{1}$ et $0,9 \mathrm{p} .100$ avec la $\mathrm{JH}_{2}$. Diverses méthodes de préparation des échantillons biologiques pour les RIAs sont décrites et discutées.

\section{References}

BAEHR J. C., PRADELleS P., LEBREUX C., CASSIER P., DRAY F., 1976. A simple and sensitive radioimmunoassay of Insect Juvenile Hormone using an iodinated tracer. FEBS Letfers, 69, 123-128.

BAEHR J. C., PORCHERON P., DRAY F., 1978. Dosages radioimmunologiques des ecdystéroïdes ef des hormones juvéniles au cours des deux derniers stades larvaires de Rhodnius prolixus (Stal) Insecte hémiptère Reduviidae. C. R. Acad. Sci. Paris, Sér. D, 287, 523-526. 
BAEHR J. C., PORCHERON P., PAPILLON M., DRAY F., 1979. Haemolymph levels of juvenile hormone, ecdysones and protein during the last two larval stages of Locusta migratoria. J. Insect Physiol, 25, 415-421.

CARUELLE J. P., BAEHR J. C., CASSIER P., 1979. Synthèse d'hormones juvéniles in vitro pour les Corpora allata de larves du $5^{e}$ stade de Locusfa migratoria migratorioides (R. et F.) (Insecte, Orthopteroïde). C. R. Acad. Sci. Paris, Sér. D, 288, 1107-1110.

CAUSSANEL C., BAEHR J. C., CASSIER P., DRAY F., PORCHERON P., 1979. Corrélations humorales ef ultrastructurales au cours de la vitellogénèse et de la période de soins aux œufs chez Labidura riparia (Insecte, Dermaptera). C. R. Acad. Sc. Paris, Sér. D, 288, 513-516.

GIESE C., SPINDLER K. D., EMMERICH H., 1977. The solubility of Insect Juvenile Hormone in aqueous solutions and its adsorption by glassware and plastics. Z. Naturforsch., 32C, 158-160.

GRANGER N. A., BOLLENBACHER W. E., VINCE R., GILBERT L. I., BAEHR J. C. DRAY F., 1979. In vitro biosynthesis of Juvenile hormone by the larval Corpora allata of Manduca sexta : quantification by radioimmunoassay (in preparation).

LAUER R. C., SALOMON P. H., NAKANISHI K., ERLANGER B. F., 1974. Antibodies to Insect C-16 Juvenile hormone. Experientia, 15, 558-560.

LENSKY Y., BAEHR J. C., PORCHERON P., 1978, Dosages radioimmunologiques des ecdysones ef des hormones juvéniles au cours du développement post-embryonnaire chez les ouvrières et les reines d'abeille (Apis mellifera L, var. ligustica). C. R. Acad. Sci. Paris, Sér. D, 287, 821-824.

PAPILLON M., PORCHERON P., BAEHR J. C., 1979. Taux hémolymphatiques d'hormones juvéniles $\left(\mathrm{JH}_{1}\right.$ ef $\left.\mathrm{JH}_{3}\right)$ d'ecdystéroïdes ef de protéines au cours des deux derniers stades larvaires de Schistocerca gregoria : effects de la température. Experientia (in press).

PENER M. P., ORSHAN L., DE WILDE J., 1978. Precocene II cause atrophy of Corpora allata in Locusta migratoria. Nature, 272, 350-353.

PRATT G. E., TOBE S. S., 1974. Juvénile hormones radiobiosynthetised by Corpora allata of adult female Lucusts in vitro. Life Sci., 14, 575-586.

SCHOOLEY D. A., 1977. Analysis of the naturally occuring juvenile hormones their isolation, identification and titer determination at physiological level, 241-288. In TURNER R. B. Analytical biochemistry of insects. Elsevier Sc. Publ. Comp. Amsterdam, Oxford, N. Y.

SCHOONEVELD H., 1978. Precocene-induced Corpus allatum degradation in the migratory locust, Locusta migratoria. Eighth int. Symp. Comparative Endocrinology, Amsterdam.

SCHOONEVELD H., 1979. Precocene induced collapse and resorption of Corpora allata in nymphs of Locusta migratoria. Experientia, 35, 363-364. 